\title{
INTEGRASI SAPI POTONG TANAMAN SAWIT (SISKA) DAN POTENSI PENGEMBANGANNYA DI KABUPATEN PASAMAN BARAT (Studi Kasus Kelompok Tani Lubuak Gadang, Kecamatan Luak Nan Duo)
}

\author{
Arfa ${ }^{i}{ }^{1}$, dan Yuliaty Shafan Nur ${ }^{2}$, \\ ${ }^{1}$ Program Studi Sosial Ekonomi, ${ }^{2}$ Nutrisi dan Teknologi Pakan \\ Fakultas Peternakan Universitas Andalas, Padang
}

\begin{abstract}
ABSTRAK
Tujuan dari penelitian adalah menganalisis: (1) Pelaksanaan integrasi sapi potong dan tanaman kelapa sawit, (2) Kendala-kendala yang dihadapi dalam pelaksanaan integrasi sapi potong dengan tanaman kelapa sawit. Penelitian dilakukan pada Kelompok Tani Lubuk Gadang Kecamatan Luhak Nan Duo Kabupaten Pasaman Barat. Yang mendapat bantuan program integrasi sapi potong dan tanaman kelapa sawit. Metode yang digunakan metode survey dan observasi langsung kelapangan, menggunakan kuesioner, responden yang digunakan anggota kelompok tani-ternak yang menjalankan program integrasi sapi sawit (SISKA) sebanyak 16 orang. Analisis data yang digunakan berupa analisis deskriptif dan membandingkan hasil yang diperoleh dengan sasaran dari program integrasi itu sendiri. Hasil penelitian menunjukkan bahwa integrasi sapi potong dengan tanaman kelapa sawit belum optimal. Pakan yang diberikan pada ternak sapi berupa rumput unggul dan dan rumput lapangan yang berasal dari lahan perkebunan kelapa sawit, sementara dari limbah tanaman sawit berupa hijauan disekitar tanaman sudah dimanfaatkan sementara pelapah dan daun kelapa sawit belum dimanfaatkan, limbah industri kelapa sawit berupa lumpur sawit, serat sawit, dan bungkil inti sawit belum dimanfaatkan. Pemanfaatan feses ternak sapi sebagai pupuk tanaman sawit telah dimanfaatkan, akan tetapi dalam bentuk pupuk yang belum diolah. Kendala yang dihadapi dalam pelaksanaan integrasi sapi potong dengan tanaman kelapa sawit adalah pengetahuan peternak yang kurang tentang integrasi, serta penguasaan teknologi pengolahan limbah ternak maupun limbah tanaman sawit masih rendah, sehingga penerapan integrasi belum optimal dilakukan.
\end{abstract}

Kata kunci: integrasi, sapi potong, kelapa sawit, Kabupaten Pasaman Barat

\begin{abstract}
The aim of the study was to analyze: (1) integration of beef cattle and oil palm plantations and development potential; and (2) the constraints faced in the implementation of integration programs of beef cattle and oil palm plantations. The study was conducted at farmer groups (Lubuak Gadang) in the vilage of Luhak Nan Duo County, District of East Pasaman. The study used survey method and direct observation to localized research using questionnaires. The results showed that the integration between beef cattle and oil palm plants not take place optimally, oil palm waste is not utilization for animal feed, while the use of organic vertilizer for oil palm crop has reached $100 \%$ in the form of unprocessed vertilizer. Obstacles encountered in the implementation of the integration of beef cattle and crops are oil palm farmers lack knowledge about integration and limited their knowledge of livestock waste treatment technology and feed processing of oil palm crop waste, so that the application of the integration between beef cattle and crop oil palm is not optimal.
\end{abstract}

Key words: Beef cattle integration, oil palm, District of west Pasaman

\section{PENDAHULUAN}

Penurunan populasi ternak ruminansia diduga disebabkan oleh semakin sempitnya lahan pangan yang dikonversi menjadi lahan perkebunan, disamping itu semakin kecilnya kepemilikan lahan tanaman pangan, yang berakibat berkurangnya ketersediaan rumput dan sisa-sisa hasil pertanian yang tidak mencukupi kebutuhan pakan.

Kebun kelapa sawit berpotensi dapat mencukupi kebutuhan pakan ruminansia khusus-nya sapi potong untuk peningkatan populasi sapi potong. Tanaman hijauan pakan yang berada diantara tanaman sawit, pelepah dan daun sawit, lumpur sawit, serat sawit, dan bungkil inti sawit berpotensi sebagai salah satu sumber pakan sapi potong, maka pemerintah 
mengeluarkan program bantuan untuk pengembangan sapi potong berbasis kelapa sawit dalam bentuk sistem integrasi sapi kelapa sawit (SISKA) (Dirjen Bina Produksi Peternakan, 2012).

Setiawan (2000) mengemukakan konsep LEISA (Low External Input Suistinable Agriculture) yang menekankan keterpaduan antar berbagai komponen dengan meman-faatkan sumberdaya yang tersedia secara efisien, ekonomis dan ramah lingkungan, aplikasi secara sederhana menjadi Integrated Farming System (IFS). Konsep ini melibatkan petani-ternak, pendekatan optimalisasi penggunaan bahan baku yang terdapat di lingkungan sekitar secara terpadu, penggunaan sumberdaya ditekankan pada efisiensi untuk meningkatkan pendapatan petani-ternak. Dasar pertimbangan konsep ini adalah kegiatan produksi pertanian tanaman dan ternak dengan prinsip zero waste, yang dimaksud dengan zero waste adalah mengoptimalkan pemanfaatan sumberdaya lokal, seperti jerami padi, pucuk tebu, kulit buah kakao, kulit buah kopi, serat sawit sebagai pakan ternak melalui proses fermentatif agar mempunyai nilai guna yang lebih baik dan kotoran ternak sapi diproses menjadi pupuk organik. Artinya memperbaiki unsur hara yang dibutuhkan tanaman sehingga tidak ada limbah yang terbuang (Ditjen Peternakan, 2002).

Kelompok tani Lubuak Gadang merupakan salah satu kelompok tani yang mendapat program bantuan integrasi sapi sawit dari dana APBN. Kelompoktani ini mulai berdiri semenjak tahun 1983, beranggotakan 16 orang dan mulai mendapat bantuan program integrasi pada awal September 2012, berupa bantuan sapi Bali sebanyak 28 ekor (26 ekor betina induk dan 2 ekor pejantan). Pada saat penelitian sapi yang ada berjumlah 27 ekor, hal ini disebabkan karena produktivitas masih rendah sebagai akibat dari belum optimalnya pelaksanaan program ditingkat anggota.

Penelitian ini bertujuan untuk menganalisis : (1) integrasi sapi potong dengan tanaman sawit dan potensi pengembangannya; (2) kendala-kendala yang dihadapi dalam pelaksanaan program dan solusinya, pada Kelompok Tani Lubuak Gadang kecamatan Luak Nan Duo.

\section{MATERI DAN METODE}

\section{Lokasi dan Waktu Penelitian}

Penelitian dilakukan di Kelompok Tani Lubuak Gadang kenagarian Kapa, Kecamatan Luak Nan Duo, Kabupten Pasaman Barat, berlangsung selama tiga bulan.

\section{Metode Penelitian}

Penelitian menggunakan metoda survei, melalui wawancara dan observasi langsung ke lokasi penelitian.
Wawancara dilakukan dengan mendatangi masingmasing responden berdasarkan kuesioner yang telah disusun. Data sekunder di peroleh dari instansiinstansi terkait seperti BPS Kabupaten Pasaman Barat, Dinas Peternakan Kabupaten Pasaman Barat dan Kantor Camat Luak Nan Duo.

\section{Responden Penelitian}

Responden pada penelitian ini ditetapkan secara sensus yakni semua anggota kelompok tani Lubuak Gadang yang mendapat program bantuan integrasi sapi sawit sebanyak 16 orang.

\section{Peubah dan Pengukuran}

Peubah yang di amati pada penelitian ini adalah sebagai berikut:

1. Karakteristik kelompok pelaksana program

2. Alokasi Dana program

3. Usaha sapi potong

4. Usaha tanaman Kelapa Sawit

5. Pemanfaatan Limbah

6. Kendala-kendala yang di hadapi dalam penerapan integrasi sapi potong dengan tanaman sawit

\section{Analisis Data}

Data yang diperoleh dianalisis secara deskriptif dan disajikan dalam Tabel, Gambar dan Grafik, kemudian dibandingkan dengan petunjuk teknis pelaksanaan integrasi ternak dan tanaman. Untuk mengetahui permasalahan yang dihadapi oleh anggota dilihat dari alasan mereka terkait dengan pencapaian sasaran program dan pengetahuan mereka terhadap penggunaan teknologi pendukung integrasi.

\section{HASIL DAN PEMBAHASAN}

\section{Gambaran Umum Lokasi Penelitian}

Kecamatan Luak Nan Duo berada pada ketinggian diantara 0-250 $\mathrm{m}$ dpl dengan suhu udara berkisar antara $20^{\circ}-26^{\circ} \mathrm{C}$ dan kelembaban udara sekitar $88 \%$, curah hujan berada diantara 1.500-4.000 mm per tahun. Luas lahan yang ada lebih kurang 17.421 Ha, $8.550 \mathrm{Ha}(49 \%)$ diantaranya berupa lahan perkebunan, dan dari lahan perkebunan tersebut $6.180 \mathrm{Ha}(72,28 \%)$ berupa lahan kebun sawit. Populasi ternak ruminansia 4.925 ekor, 3.115 ekor (63.25\%) diantaranya adalah ternak sapi, sedangkan sisanya berupa ternak kerbau, kambing dan domba (Luhak Nan Duo dalam Angka, 2012). Hal ini menggambarkan bahwa komoditas perkebunan dan ternak yang menonjol diwilayah ini merupakan ternak sapi dan perkebunan kelapa sawit, dan ini yang menjadi pertimbangan program integrasi antara sapi dan sawit dilaksanakan. 
Profil Kelompok Tani Pelaksana Program Integrasi

Profil kelompok tani ternak pelaksana program integrasi sapi potong dan tanaman Kelapa Sawit disajikan pada Tabel 1. Kelompok tani Lubuak Gadang berdiri semenjak tahun 1983 mulai melaksanakan program integrasi pada bulan September 2012, disini terlihat bahwa kelompok sudah terbentuk jauh hari sebelum program bantuan ini ada. Dari segi pembentukan kelompok sangat mendukung adanya program integrasi antara sapi potong dan tanaman Kelapa Sawit.

Tabel 1. Karakteristik kelompok tani pelaksana bantuan integrasi

\begin{tabular}{clc}
\hline No & \multicolumn{1}{c}{ Uraian } & Keterangan \\
\hline 1 & Nama Kelompok & Lubuak Gadang \\
2 & Tahun Berdiri & 1983 \\
3 & Jumlah anggota & 16 \\
4 & Tahun menerima bantuan sapi & September 2012 \\
5 & Kelembagaan & Kelompok Tani \\
6 & Status Kelompok saat penelitian & Lanjut \\
\hline
\end{tabular}

Sumber: Hasil Peneltian (2014)

\section{Alokasi Dana Bantuan Program Integrasi}

Alokasi dana bantuan prorgam integrasi ternak sapi dan tanaman Sawit pada kelompok tani Lubuak Gadang disajikan pada Tabel 2.

Tabel 2. Alokasi dana bantuan program integrasi

\begin{tabular}{|c|c|c|c|c|}
\hline No & Uraian & Volume & Jumlah & Persentase \\
\hline 1 & $\begin{array}{l}\text { Pembelian sapi potong } \\
\text { (Bali) }\end{array}$ & 28 ekor & 210.000 .000 & 70 \\
\hline 2 & Mesin pengolah pakan & 1 unit & 45.000 .000 & 15 \\
\hline 3 & $\begin{array}{l}\text { Pembelian bibit Hi- } \\
\text { jauan pakan dan sarana } \\
\text { produksi }\end{array}$ & 1 paket & 30.000 .000 & 10 \\
\hline 4 & $\begin{array}{l}\text { Administrasi kelompok } \\
\text { dan pelaporan }\end{array}$ & 1 paket & 15.000 .000 & 5 \\
\hline \multicolumn{2}{|c|}{ Jumlah } & & 300.000 .000 & 100 \\
\hline
\end{tabular}

Sumber : Hasil Penelitian (2014)

Hasil penelitian menjelaskan bahwa pemanfaatan dana bantuan untuk pengadaan sapi potong masih kurang (70\%), berdasarkan petunjuk teknis integrasi sapi dan tanaman penggunaan dana untuk pengadaan sapi minimal 85 persen dan sisanya digunakan untuk fasilitas penunjang integrasi. Realisasi penggunaan dana yang kurang disebabkan oleh pengawasan yang kurang dari pemerintah setempat terhadap program yang diberikan, dan hal ini tentunya akan mempengaruhi keberhasilan program yang dijalankan.

\section{Karakteristik Petani-ternak}

Karakteristik peternak sapi potong penerima bantuan terdiri dari, peternak berada pada usia produktif (100\%), tingkat pendidikan masih rendah SD (56\%), memiliki pengalaman beternak 5-10 tahun (81\%), dan pekerjaan utama sebagai petaniternak (100\%). Disamping umur produktif tingkat pendidikan formal turut mempengaruhi petani ternak dalam mengelola usaha, semakin rendah tingkat pendidikan akan semakin rendah pula wawasan dalam mengelola usaha yang dijalankan, dengan demikian akan semakin lambat dalam menerima inovasi teknologi.

\section{Usaha Ternak Sapi Potong}

Bibit dan Perkembangan sapi yang dipelihara. Bibit dan perkembangan sapi yang dipelihara disajikan pada Tabel 3. Hasil penelitian menunjukkan bahwa jenis bibit yang dipelihara terdiri dari sapi Bali (100\%), ternak dikawinkan melalui IB. Bila dibandingkan dengan awal program sudah terlihat perkembangan sapi yang dipelihara sebesar 25 persen selama dua tahun (rata-rata peningkatan $12,5 \% /$ tahun). Rendahnya perkembangan populasi disebabkan oleh rendahnya angka kelahiran $(16,1 \%)$ dan angka kematian yang tinggi (3,6\%), hal ini berkaitan dengan tingkat pendidikan peternak yang masih rendah, kualitas bibit sapi Bali yang masih kurang baik sebagai bibit. Alasan peternak memilih sapi Bali sebagai bibit sebetulnya sudah bagus akan tetapi tidak dibarengi dengan seleksi terhadap bibit sapi Bali yang digunakan, perkawinan sapi dilakukan secara IB keragaan reproduksi usaha ternak sapi potong disajikan pada Tabel 4 .

Tabel 3. Bibit dan perkembangan sapi program integrasi

\begin{tabular}{clccc}
\hline No & Rincian & Bangsa Sapi & Awal (ekor) & $\begin{array}{c}\text { Saat Peneli- } \\
\text { tian (ekor) }\end{array}$ \\
\hline 1. & Jantan Dewasa & Bali & 2 & 2 \\
& Betina Dewasa & Bali & 26 & 25 \\
2. Jantan Muda & Bali & - & - \\
& Betina Muda & Bali & & \\
3. Anak Jantan & Bali Bali & - & 2 \\
& Anak Betina & & & 6 \\
& Jumlah & & 28 & 35 \\
Perkembangan (\%) & & & 25 \\
\hline
\end{tabular}

Sumber : Hasil Penelitian (2014)

Tabel 4. Keragaan reproduksi usaha pembibitan sapi potong

\begin{tabular}{ccc}
\hline No & \multicolumn{1}{c}{ Komponen,1 } & Keterangan \\
\hline 1. & Calving Interval & 15 bulan \\
2. & Service per Conception (S/C) & 1,9 \\
3. & Masa Kosong & 4,5 bulan \\
\hline
\end{tabular}

Sumber : Hasil penelitian (2014)

Calving interval yang didapat relatif panjang yaitu mencapai 15 bulan, sedangkan interval yang baik adalah sekitar 12 bulan. Hal ini karena masih tebatasnya pelayanan IB oleh petugas (jumlah petugas yang kurang), sehingga waktu IB terlambat dan molor. Siregar et al. (1998) menyatakan bahwa keberhasilan IB dipengaruhi oleh berbagai 
faktor, yakni kondisi sapi, akseptor, keterampilan inseminator, keterampilan peternak dalam mengamati siklus berahi, dan ketepatan waktu pelaksanaan IB.

Pakan yang diberikan. Jenis pakan yang diberikan hanya berupa hijauan yang terdiri dari hijauan unggul (rumput gajah), rumput lapangan, dan leguminosa (gamal) dengan perbandingan 5 : 80 : 15 , dengan rata-rata pemberian $17,5 \mathrm{~kg} / \mathrm{ut} /$ hari. Hijauan unggul ditanam dilahan masing-masing peternak dengan luas lahan rata-rata 0,2 ha/peternak, sedangkan rumput lapangan dan leguminosa ditanam di lahan kelapa sawit yang mereka milikki (ratarata kepemilikan lahan sawit 1,31 ha//peternak). Penggunaan limbah sawit sebagai pakan ternak belum dimanfaatkan, hal ini disebabkan karena pakan hijauan masih banyak tersedia, dan pengetahuan peternak yang masih rendah terhadap pengolahan limbah sawit sebagai pakan ternak.

Tatalaksana Pemeliharaan. Sisitem pemeliharaan sapi dilakukan secara intensif sehingga memudahkan pengontrolan terhadap ternak, pengumpulan feses, dan perkawinan. Kandang ternak dibuat sesederhana mungkin dengan memanfaatkan bahan lokal yang ada, sebagian besar bangunan kandang terbuat dari kayu, atap seng, lantai kandang dari semen, dinding dari kayu dan bambu, ukuran kandang 2 x 1,5 $\mathrm{m}^{2}$ per unit ternak. Kandang umumnya dibersihkan setiap hari, peralatan kandang terdiri dari tempat pakan, tempat minum dan penampungan kotoran.

Prediksi feses yang dihasilkan. Jumlah kotoran sapi yang dihasilkan dapat diprediksi dari jumlah sapi yang dipelihara. Budiyanto (2011) menyatakan bahwa rata-rata satu Satuan Ternak sapi Bali yang dipelihara menghasilkan $7 \mathrm{~kg}$ kotoran kering per hari, maka kotoran kering yang dihasilkan dari 29 ST sapi yang dipelihara kelompok adalah sebesar $203 \mathrm{~kg} / \mathrm{ST} / \mathrm{hr}$, atau setara dengan 74,095 ton pupuk organik per tahun. Jika kebutuhan pupuk organik untuk lahan kelapa sawit rata-rata 2 ton/ha/th, dengan pupuk organik yang dihasilkan akan dapat memenuhi kebutuhan pupuk organik lahan kelapa sawit seluas 37,05 Ha. Luas lahan kelapa sawit yang dimilikki oleh anggota sebesar $21 \mathrm{Ha}$, sehingga masih tersisa pupuk organik untuk kebutuhan lahan sawit seluas 16,05 ha.

\section{Usaha Tanaman Kelapa Sawit}

Luas Tanam. Luas tanaman kelapa sawit milik anggota kelompok sebesar $21 \mathrm{Ha}$, sehingga ratarata luas tanaman masing-masing anggota kelompok adalah sebesar 1,31 Ha, jarak antara kebun sawit dengan kandang sapi potong cukup dekat lebih kurang 500 meter, sehingga memudahkan dalam kegiatan integrasi.

Pemupukan. Pemupukan yang dilakukan oleh petani-ternak terhadap tanaman sawit berupa pupuk organik dari feses sapi yang belum diolah dan pupuk an-organik berupa Urea, TSP, KCl. Jumlah pupuk organik yang diberikan sebanyak 2 ton/ha/th yang diberikan dalam 2 kali periode, sedangkan pupuk urea diberikan sebanyak $200 \mathrm{~kg} / \mathrm{ha} / \mathrm{th}$, TSP $100 \mathrm{~kg} / \mathrm{ha} /$ th, dan $\mathrm{KCl}$ sebanyak $100 \mathrm{~kg} / \mathrm{ha} /$ th diberikan dalam 2 kali periode pemberian.

\section{Potensi Limbah Kelapa Sawit sebagai Pakan Ternak}

Selain vegetasi alam yang diperoleh dari Hijauan Antara Tanaman (HAT) sumber pakan berasal dari limbah kelapa sawit yang dapat digunakan berupa pelepah dan daun kelapa sawit, sedangkan dari pabrik pengolahan kelapa sawit berpotensi menghasilkan bungkil inti sawit, lumpur sawit (solid) dan serabut buah sawit (serat sawit).

Tanaman hijauan disekitar tanaman sawit. Hasil penelitian Doru et al (2014) didapatkan bahwa produksi hijauan antar tanaman sawit sebesar 3,205 ton $\mathrm{BK} / \mathrm{ha} / \mathrm{th}$, produksi hijauan pakan dari lahan yang dimilikki anggota kelompok sebesar 67,305 ton BK/ ha/th. Jika 1 ekor sapi dewasa berat hidup $250 \mathrm{~kg}$ membutuhkan pakan sebesar 2,3 ton BK/th, maka dari tanaman pakan sekitar tanaman sawit dapat menampung sekitar 29,26 UT/th.

Pelepah dan Daun Kelapa Sawit. Hasil penelitian Doru et al (2014) didapatkan bahwa 1 (satu) ha kebun sawit menghasilkan pelepah dan daun sawit sebesar 18.083,5 kg BK/th, produksi pelepah dan daun sawit yang dihasilkan dari lahan milik anggota sebesar 379.753,5 kg BK/th. Jika 1 ekor sapi dewasa berat hidup $250 \mathrm{~kg}$ membutuhkan pakan sebesar 2,3 ton $\mathrm{BK} / \mathrm{th}$, maka potensi pakan yang berasal dari pelepah dan daun sawit adalah sebesar 1.651 UT/th.

Lumpur Sawit (sludge). Hasil penelitian Doru et al (2014) didapatkan bahwa 1 ha kebun sawit menghasilkan lumpur sawit sebesar 26,5 ton BK/ th, produksi lumpur sawit dari lahan sawit yang dimilikki anggota sebesar 556,5 ton BK/th, dan hal ini dapat menampung ternak sapi potong sebesar 241,96 UT/TH.

Bungkil Inti Sawit (BIS). Hasil penelitian Doru et al (2014) didapatkan bahwa 1 ha kebun sawit dapat menghasilkan bungkil inti sawit sebesar $470,58 \mathrm{~kg}$ $\mathrm{BK} /$ th, produksi BIS dari lahan sawit milik anggota kelompok adalah sebesar 9.882,18 kg BK/th, dan dapat menampung ternak sapi potong sebanyak 4,29 $\mathrm{UT} / \mathrm{th}$

Serat Sawit. Hasil penelitian Doru et al (2014) didapatkan bahwa 1 ha kebun sawit dapat menghasilkan serat sawit sebesar 183,59 kg BK/th, produksi serat sawit dari lahan sawit milik anggota kelompok adalah sebesar 3.855,39 kg/th, dan dapat menampung ternak sapi potong sebanyak 1,67 UT/th 
Potensi pakan yang tersedia untuk pengembangan ternak sapi potong dari seluas 21 ha kebun sawit milik anggota adalah sebesar 1.928,18 UT/th (91,82 UT/ ha/th), yang baru ter-manfaatkan sebesar 29 UT dan masih memilikki potensi pengembangan sebesar 1.899,18 UT.

\section{Pemanfaatan Limbah di Lokasi Penelitian}

Pemanfaatan Limbah Ternak untuk Pupuk Tanaman Kelapa Sawit. Hasil penelitian menunjukan bahwa pupuk organik yang dihasilkan telah dimanfaatkan oleh anggota kelompok tani-ternak program integrasi. Pupuk organik yang mereka gunakan berasal dari feses ternak sapi yang dipelihara, diolah secara sederhana dengan cara : feses ditempatkan disuatu tempat penampungan feses disekitar kandang (memiliki atap sederhana), feses disimpan selama 5 minggu sambil dibalik tanpa ada perlakuan lain, setelah lima minggu pupuk organik yang sudah jadi langsung digunakan untuk tanaman sawit. Pupuk organik yang dihasilkan masih bisa dioptimalkan melalui teknologi pengolahan pupuk, sehingga nilai haranya bias ditingkatkan dan diharapkan diharapkan dapat mengurangi penggunaan pupuk anorganik dari luar usaha, sehingga biaya pupuk an-organik bisa dikurangi dan efisiensi usaha dapat ditingkatkan. Adanya keterkaitan antara usahatani tanaman dan usaha ternak dapat meningkatkan efisiensi usahataniternak sehingga dapat meningkatkan produktivitas dan pendapatan petani (Diwyanto dan Priyanti, 2006).

Pemanfaatan Limbah Tanaman Sawit untuk

Pakan Ternak. Pemanfaatan limbah tanaman sawit untuk pakan ternak disajikan pada Tabel 5 .

Tabel 5. Pemanfaatan limbah sawit didaerah penelitian

\begin{tabular}{lcccc}
\hline \multirow{2}{*}{ No Rician } & \multicolumn{4}{c}{ Frekuensi Pemanfaatan } \\
\cline { 2 - 5 } & $\begin{array}{c}\text { Meman- } \\
\text { faatkan }\end{array}$ & $\%$ & $\begin{array}{c}\text { Belum diman- } \\
\text { faatkan }\end{array}$ & $\%$ \\
\hline 1 Hijauan yang ada disekitar & 16 & 100 & -- & -- \\
$\quad \begin{array}{l}\text { tanaman } \\
2 \text { Pelepah dan daun sawit }\end{array}$ & -- & -- & 16 & 100 \\
3 Limbah industri & & & & \\
$\quad-$ Lumpur sawit & -- & -- & 16 & 100 \\
$\quad$ - Serat sawit & -- & -- & 16 & 100 \\
$\quad$ - BIS & -- & -- & 16 & 100 \\
\hline
\end{tabular}

Sumber : Hasil penelitian (2014)

Hasil penelitian menunjukkan bahwa hijauan yang tumbuh disekitar tanaman sawit sudah dimanfaatkan oleh peternak sebagai pakan, sementara pelepah dan daun sawit, lumpur sawit, serat sawit, dan BIS belum dimanfaatkan sebagai pakan, karena menurut mereka hijauan yang tersedia disekitar areal masih cukup tersedia untuk sejumlah ternak yang mereka pelihara.

\section{Kendala dalam Pelaksanaan Program Integrasi}

Kendala yang dihadapi oleh petani-ternak dalam melaksanakan program integrasi disajikan pada Ta- bel 6 .

Tabel 6. Kendala yang dihadapi dalam pelaksanaan integrasi

\begin{tabular}{|c|c|c|c|}
\hline No & Rincian & Frekuensi & Persentase \\
\hline 1 & $\begin{array}{l}\text { Kurangnya pengetahuan tentang } \\
\text { integrasi }\end{array}$ & 12 & 75 \\
\hline 2 & $\begin{array}{l}\text { Penguasaan Teknologi pengolahan } \\
\text { limbah ternak }\end{array}$ & 16 & 100 \\
\hline 3 & $\begin{array}{l}\text { Penguasaan teknologi pengolahan } \\
\text { limbah sawit }\end{array}$ & 16 & 100 \\
\hline
\end{tabular}

Sumber : Hasil Penelitian (2014)

Hasil penelitian menunjukan bahwa masih kurangnya pengetahuan petani-ternak tentang integrasi antara tanaman dan ternak, hal ini terlihat dari pupuk organik yang digunakan masih belum diolah, pada hal jika pupuk organik yang diolah potensi penggunaannya dapat ditingkatkan terutama kadar unsur hara yang dibutuhkan oleh tanaman. Begitu juga dengan penguasaan teknologi pengolahan limbah tanaman sawit sebagai pakan ternak masih sangat kurang, hal lain yang berkontribusi terhadap belum optimalnya pelaksanaan integrasi karena hijauan yang tersedia masih mencukupi kebutuhan ternak yang dipelihara, hijauan berasal dari lahan hijauan yang mereka punya, rata-rata luas lahan hijauan yang mereka punya adalah sekitar 0.2 ha yang ditanami dengan rumput gajah.

\section{SIMPULAN DAN SARAN}

\section{Simpulan}

Berdasarkan hasil dan pembahasan dapat ditarik kesimpulan sebagai berikut:

1. Pelaksanaan program integrasi sapi potong dan tanaman sawit belum optimal, limbah ternak sapi sudah dimanfaatkan untuk pupuk tanaman sawit, sedangkan limbah sawit belum dimanfaatkan sebagai pakan ternak, karena pakan yang tersedia masih mencukupi untuk ternak yang mereka pelihara.

2. Kendala yang dihadapi dalam pelaksanaan program integrasi sapi potong dan tanaman sawit adalah karena pengetahuan dan keterampilan petaniternak masih rendah.

\section{Saran}

Untuk mengoptimalkan pelaksanaan program integrasi dimasa mendatang disarankan hal berikut peningkatan pengetahuan peternak tentang integrasi tanaman dan ternak melalui penyuluhan dan pelatihan, terutama dibidang teknologi pengolahan limbah tanaman untuk pakan ternak dan pengolahan limbah ternak untuk pupuk tanaman. 


\section{DAFTAR PUSTAKA}

Budiyanto, K. 2011. Tipologi Pendayagunaan Kotoran Sapi dalam Upaya Mendukung Pertanian Organik di Desa Sumbersari Kecamatan Poncokusumo Kabupaten Malang. Jurnal Gamma 7 (1) 42-49

Direktorat Jendral Bina Produksi Peternakan. 2012. Pedoman Umum Integrasi Tanaman dan Ternak. Jakarta

Direktorat Jenderal Peternakan. 2002. Pedoman Teknis Bantuan Pinjaman Langsung Masya-rakat (BPLM) Berbasis Pemberdayaan Kelompok Peternak. Direktorat Jenderal Bina Produksi Peternakan. Departemen Pertanian, Jakarta.

Diwyanto, K., dan A, Priyanti. 2006. Kondisi, potensi dan permasalahan agribisnis peter-nakan ruminansia dalam mendukung ketahanan pangan. Proc. Seminar Nasional Pem-berdayaan Masyarakat Peternakan di Bidang Agribisnis untuk Mendukung Ketahanan Pangan. Fakultas Peternakan UNDIP, Semarang 3 Agustus 2006, hal : 1-11 Daru, T.P; Arlina, Y; dan Eko, W. 2014. Potensi Hijauan di Perkebunan Kelapa Sawit sebagai Pakan Sapi Potong di Kabupaten Kutai Kartanegara. Media Sains Volume 7 Nomor 1, hal 79-86.

Luhak Nan Duo dalam Angka. 2012. Kerjasama Badan Pusat Statistik dengan Bappeda Kabupaten Pasaman Barat

Setiawan. 2000. Sistem Pertanian Terpadu. Majalah AT Agribisnis 143:24-26.

Siregar, A.P., P. Situmorang, dan K. Diwyanto. 1998. Pemanfaatan teknologi IB dalam upaya ppeningkatan produktivitas sapi potong di Indonesia. Proc. Seminar Nasional Peternakan dan Veteriner, Puslitbangnak. Bogor. 